\title{
Methodology for studying the composition of non-interlamellar pore water in compacted bentonite
}

\author{
JOONAS JÄRVINEN*, MICHAŁ MATUSEWICZ AND AKU ITÄLÄ \\ VTT Technical Research Centre of Finland Ltd, P.O. Box 1000, FI-02044 VTT, FINLAND
}

(Received 31 May 2015; revised 07 February 2016; Guest Editor: Maarten Van Geet)

\begin{abstract}
Many safety functions required of the compacted bentonite buffer in the KBS-3 concept rely on processes influenced by the composition of the pore water. Important safety-relevant processes are related to the bentonite buffer, e.g. swelling, precipitation and dissolution reactions, and transport of water, colloids and ions. One of the methods used in analysing pore water in compacted bentonite is the 'squeezing technique'. Various possible artefacts which can occur during squeezing, such as mixing of different pore-water types, dissolution of accessory minerals and cation exchange, need special attention.

The present work describes the methodology for studying the composition of the non-interlamellar pore water by combining squeezing methods, chemical analyses, microstructure measurements and geochemical modelling. Four different maximum pressures were used to squeeze the compacted bentonite pore water. The origin of the pore water was studied by analysing the bentonite microstructure both before and after squeezing using SAXS and NMR, the cation exchange and dissolution reactions were studied by chemical analyses and geochemical modelling.

The pore-water yield increased from 32 to $48 \mathrm{wt} . \%$ from the initial amount of pore water in the samples when the maximum squeezing pressure was increased from $60 \mathrm{MPa}$ to $120 \mathrm{MPa}$. About $35 \mathrm{wt} . \%$ of the water collected originated from the interlamellar (IL) pores. The ratio between IL and non-IL pore waters as well as the composition of the squeezed pore water was constant in the squeezing-pressure range used. The results of microstructural measurements by SAXS were in perfect agreement with previous studies (e.g. Muurinen \& Carlsson, 2013). The dissolving accessory minerals have an effect on the ratio of the cations in the squeezed solution while the migration of anions in bentonite seems to be diffusion limited. According to geochemical modelling the chloride concentration of the non-IL pore water in compacted bentonite before squeezing was $0.34 \mathrm{M}$ greater than in the squeezed pore water due to the mixing of two main water types.
\end{abstract}

KEYWORDS: bentonite, pore water, squeezing, microstructure.

The Finnish and Swedish plans for disposal of spent nuclear fuel are based on the KBS-3 concept (KärnBränsleSäkerhet, nuclear fuel safety). The spent nuclear fuel will be contained in copper canisters which will be emplaced several hundred metres deep into bedrock and surrounded by a compacted bentonite barrier

*E-mail: joonas.jarvinen@vtt.fi

DOI: 10.1180/claymin.2016.051.2.05
(Posiva, 2010; SKB, 2011). The purpose of the bentonite buffer is to maintain the integrity of the canisters and to limit and retard the release of radionuclides from the canisters. Many of the safety functions of the bentonite buffer are determined by montmorillonite and based on processes which are related to the composition of the buffer pore water. Important safety-relevant processes are, inter alia, swelling, precipitation and dissolution reactions, and transport of the water, colloids and ions (Posiva, 2010). The Wyoming MX-80 bentonite used in 
the experiments consists mainly of sodium/calcium montmorillonite, smaller amounts of other minerals (quartz, calcite, feldspar, etc.) and pore water (Muurinen, 2010; Kiviranta and Kumpulainen, 2011).

The pore water in compacted bentonite consists of interlamellar water (IL-water) and non-interlamellar water (non-IL water) (Pusch et al., 1999; Bradbury \& Baeyens, 2002; Wersin, 2003; Fernández et al., 2004; Muurinen et al., 2007; Holmboe et al., 2012; Muurinen \& Carlsson, 2013). The fraction of non-IL water in compacted bentonite changes as a function of the dry density, the salinity of the non-IL water and exchangeable cations in montmorillonite (Van Loon et al., 2007; Muurinen \& Carlsson, 2013). The exchangeable cations, external conditions, the dissolving components in montmorillonite and accessory minerals determine the composition of the non-IL water, and thereby the amounts of major ions in the non-IL water: $\mathrm{Ca}, \mathrm{Na}$, sulfate, bicarbonate, chloride, $\mathrm{Mg}$ and $\mathrm{K}$. In addition to simplified distribution of the pore water into two water types, the negative charge of the unit layers should also be taken into account when non-IL water composition is evaluated. Repulsion of the anions by the negatively charged surfaces (exclusion) restricts the anion-accessible space in the pore water which varies according to ionic strength and dry density. In the present study the anion-accessible space is referred to as chloride-accessible porosity $(\mathrm{Cl}-$ porosity) according to the anion used to evaluate the volume proportion (Bolt \& Warkentin, 1958; Van Loon et al., 2007; Muurinen, 2009; Muurinen \& Carlsson, 2013). The composition of the pore water in the compacted bentonite can be studied by, among other methods, the squeezing technique (Muurinen \& Lehikoinen, 1999; Sacchi et al., 2001; Fernández et al., 2014). Although this technique has been used successfully on highly consolidated clayrocks in many studies, the effects of squeezing on bentonites are still under study (Muurinen, 2001; Fernández et al., 2004, 2014, 2015). Due to the high pressure used in squeezing bentonite for extracting pore water, different pore-water types may mix together and cause a new chemical balance between montmorillonite, IL-water, non-IL water and the anion-accessible water. This may cause dissolution of the easily dissolving minerals in non-IL water, changes in the composition of exchangeable cations and dilution of the anion concentrations. The rate at which pore water can be squeezed from bentonite depends on the hydraulic conductivity, and the force needed in squeezing depends on the swelling pressure (Muurinen, 2006; Muurinen \& Järvinen, 2013; Fernández et al., 2014).
The aim of the present study is to develop a squeezing methodology to analyse the chemical composition of non-IL water from compacted bentonite by combining chemical analyses, measurements of microstructure and geochemical modelling. The methodology used here is a combination of techniques tested by Muurinen (2001) for squeezing tests, by Karnland et al. (2006), Muurinen (2006) and Kumpulainen \& Kiviranta (2011) for chemical analyses, and by Muurinen \& Carlsson (2013) and Matusewicz et al. (2013) for microstructure studies.

Block 1 (MX-80) from package 2 of the Alternative Buffer Material (ABM) project was used in the present study. More detailed information about the ABM project at Äspö in Sweden can be found in Svensson et al. (2011). Four fully saturated parallel samples were squeezed under anoxic conditions. The squeezing pressure was increased stepwise to a maximum value. Four maximum pressures were used: 60, 80, 100 and $120 \mathrm{MPa}$. To estimate the origin of the squeezed pore waters and to reverse calculate the initial chemical composition of non-IL pore water in the compacted bentonite, several analyses were performed. The ratios of the IL and non-IL water were determined by SAXS and NMR measurements before and after squeezing. The squeezed pore-water concentration, water content before and after squeezing, as well as the exchangeable cations, carbonates, chloride and sulfate content in oven-dried bentonite at $105^{\circ} \mathrm{C}$ were determined. A simplified conceptual model was used in geochemical modelling, where the pore water was divided into two water types, IL and non-IL waters. The exclusion effect was not included in the geochemical modelling.

\section{EXPERIMENTAL}

\section{Background of the samples}

To study the behaviour of the alternative buffer materials $(\mathrm{ABM})$ in field conditions, three packages were assembled in the Äspö Hard Rock Laboratory (HRL) at the end of 2006. The packages contained a central steel tube with a heater, and 11 different compacted clay rings. The heater target temperature was $130^{\circ} \mathrm{C}$. The clay rings had a diameter of $30 \mathrm{~cm}$ and a height of $10 \mathrm{~cm}$. The whole test package was $\sim 3 \mathrm{~m}$ high. Two of the packages were saturated artificially and the third was saturated naturally (Svensson et al., 2011). Package 2 was dismantled in 2013. Part of the lower block 1 (MX-80) of package 2 was used in these experiments. The sample studied was altered by heat and Ca-rich solution during the $7 \mathrm{y}$ of underground 


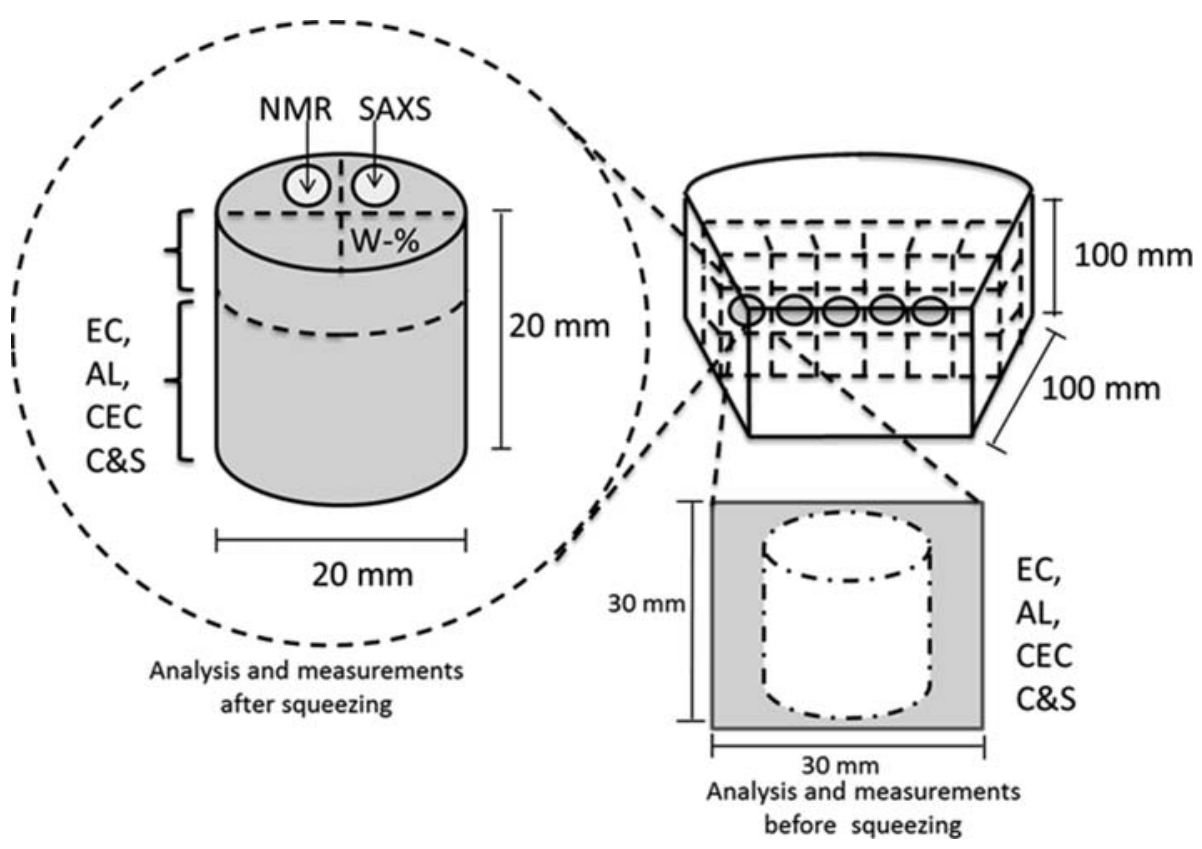

FIG. 1. Schematic representation of the cutting of block 1 into subsamples for squeezing experiments (on the upper right), and for analyses before (on the lower right) and after (on the left) squeezing. The samples for SAXS, NMR and water-content measurements were cut from the wet sample before and after squeezing and the rest of the sample was dried at $105^{\circ} \mathrm{C} . \mathrm{EC}=$ exchangeable cations, $\mathrm{AL}=$ aqueous leachates, $\mathrm{CEC}=$ cation exchange capacity, $\mathrm{C} \& \mathrm{~S}=$ total carbon + sulfur + carbonates. The grey-coloured areas are used for analyses.

experiment. Thus, the composition of the sample no longer corresponded to MX-80 bentonite. The dominant exchangeable cation was $\mathrm{Ca}$ rather than $\mathrm{Na}$, and the chloride content was greater.

\section{Sampling}

After uplift, a third of block 1 was cut by Clay Technology $\mathrm{AB}$ and enclosed in a gas-tight vacuum bag. The part of the block to be used for squeezing studies was enclosed in metal transportation vessels in inert gas and transported to VTT's laboratory where it was further cut into smaller subsamples with a band saw under anoxic conditions: (1) A $1 \mathrm{~cm}$-thick slab was cut from one side of the block to prepare $1 \mathrm{~cm}^{3}$ $(1 \mathrm{~cm} \times 1 \mathrm{~cm} \times 1 \mathrm{~cm})$ sub-samples for water content measurements. A 1-2 mm slice in contact with the rock surface was cut from these subsamples to remove sand. (2) $3 \mathrm{~cm}$-thick slabs were cut from the block to prepare $\sim 27 \mathrm{~cm}^{3}(3 \mathrm{~cm} \times 3 \mathrm{~cm} \times 3 \mathrm{~cm})$ blanks for the squeezing studies. The blanks were further cut into cylindrical sub-samples (diameter: $2 \mathrm{~cm}$, height: $2 \mathrm{~cm}$ ) with a cutting knife. Four parallel sub-samples were chosen for the squeezing experiments and one for a reference sample for microstructural and water content measurements. Leftovers from the blanks were dried at $105^{\circ} \mathrm{C}$ and used for chemical analyses to represent the state before squeezing.

The cutting scheme of block 1 is presented in Fig. 1. The cutting and shaping of the subsamples were carried out under anoxic conditions in an argonflushed glove-box. The oxygen concentration in the glove-box atmosphere during cutting of the subsamples with a band saw varied from 10 to $300 \mathrm{ppm}$ and from 1 to $10 \mathrm{ppm}$ during final preparation of the cylindrical samples. After the analyses and measurements, each sample was dried at $105^{\circ} \mathrm{C}$ for $24 \mathrm{~h}$ and enclosed in an individual vessel to await chemical analysis.

\section{Squeezing}

Pore water was squeezed from the four parallel bentonite samples (diameter: $20 \mathrm{~mm}$ and height: $20 \mathrm{~mm}$ ) with a squeezing apparatus as depicted in Fig. 2. A strong spring maintained the pressure during squeezing. The length of the frame to which the squeezing cell was fixed was adjusted with a hydraulic 
pump in order to increase the pressure. The pressure was increased stepwise to the chosen maximum pressures: 60, 80, 100 and $120 \mathrm{MPa}$. The lowest maximum pressure value was set at $60 \mathrm{MPa}$ in order to reach an adequate yield of pore water for chemical analyses $(0.8 \mathrm{~mL})$ and the upper limit $(120 \mathrm{MPa})$ was the maximum force possible with the equipment used. All the bentonite samples were squeezed at the same time with a similar procedure. The sample preparation, squeezing, $\mathrm{pH}$ measurements and $\mathrm{HCO}_{3}^{-}$titration were performed under anoxic conditions. The squeezed pore water was collected using a $2 \mathrm{~mL}$ syringe.

\section{Analysis of the clay matrix}

After squeezing, the wet clay samples were cut into pieces, and microstructure and water-content measurements were performed. The rest of the sample was dried at $105^{\circ} \mathrm{C}$ for chemical analyses. Reference samples were taken from the blanks used to prepare cylindrical squeezing samples. (Fig. 1)

The water content, weight of the water per weight of the solids, was determined by gravimetric measurement

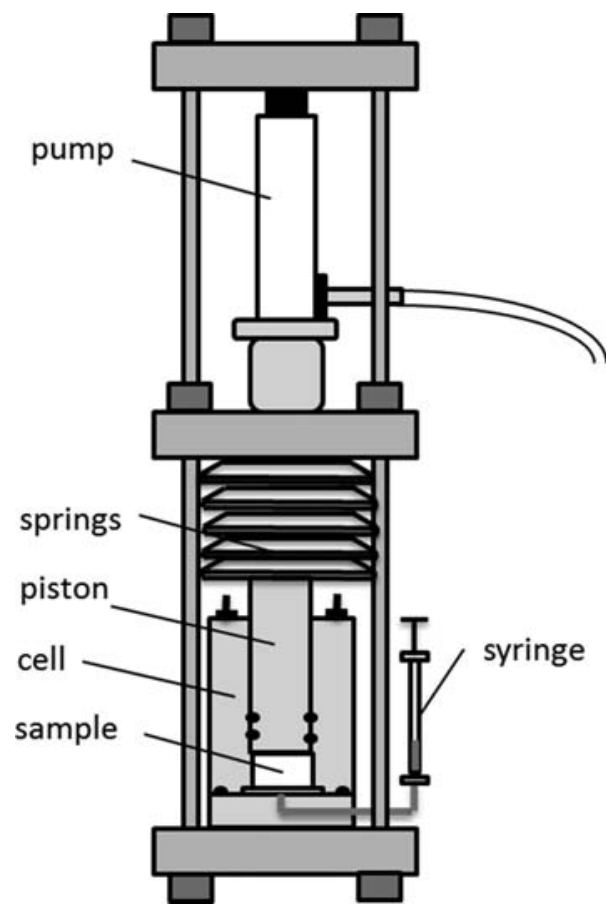

FIG. 2. Squeezing apparatus with the compaction cell $(6 \mathrm{~cm} \times 10 \mathrm{~cm})$ made of stainless steel for the bentonite sample $(2 \mathrm{~cm} \times 2 \mathrm{~cm})$ allocation and the syringe for collecting squeezed pore water (Muurinen, 2001). of weight loss at $105^{\circ} \mathrm{C}$ for a period of $24 \mathrm{~h}$. The cation exchange capacity (CEC) was determined by dispersing $0.3 \mathrm{~g}$ of dry clay in $16 \mathrm{~mL}$ of $10 \mathrm{mmol} / \mathrm{L} \mathrm{Cu}$ (II)triethylenetetramine solution. The copper adsorption was measured at $577 \mathrm{~nm}$ using a Shimadzu UV-180 spectrophotometer (Meier \& Kahr, 1999; Amman et al., 2005). The exchangeable cations were analysed by dispersing $1 \mathrm{~g}$ of dried clay in $20 \mathrm{~mL}$ of $\mathrm{NH}_{4} \mathrm{Cl}$ in $80 \%$ ethanol. Then the solution was evaporated and the solids dissolved into water, and the $\mathrm{Fe}, \mathrm{Ca}, \mathrm{K}, \mathrm{Mg}$ and $\mathrm{Na}$ cations were analysed by Inductively Coupled Plasma-Optical emission spectrometry (ICP-OES). The uncertainty of the ICP-OES analyses was $\pm 10 \%$ according to the accredited laboratory, 'Ramboll Analytics' (Vantaa, Finland). Aqueous leachates were prepared by dispersing the bentonite sample in deionized water $(0.3 \mathrm{~g} / 30 \mathrm{~mL})$ and left to soak for a week. Then the solid phases were separated by centrifuging at $8000 \mathrm{rpm}$ for $5 \mathrm{~h}$, the solution phase was ultra-filtered by $10 \mathrm{kD}$ ultra-filters and analysed using Ion Chromatography (IC). The estimated uncertainty in the IC measurements of $\mathrm{Cl}^{-}$and $\mathrm{SO}_{4}^{2-}$ was $\pm 20 \%$ and $\pm 15 \%$, respectively, according to Ramboll Analytics. The total carbon and sulfur were determined by combustion (up to $1400^{\circ} \mathrm{C}$ ) measuring the evolved $\mathrm{S}$ and $\mathrm{C}$ compounds by infrared detector. To determine carbonates, a dry sample was treated with $\mathrm{HCl}$ and the amount of total carbon was determined by an ELTRA CS 2000 device, with a detection limit of the detector at $0.05 \%$. The uncertainty of the carbonate analysis was $\pm 25 \%$ according to the accredited laboratory Labtium Oy (Kuopio, Finland). The amounts of bentonite and water that remained in the sinters were determined by gravimetric measurement of weight loss at $105^{\circ} \mathrm{C}$, before and after ultrasonic cleaning.

\section{ANALYSES OF SQUEEZED PORE WATER}

After completion of the squeezing test, the syringe was decoupled from the device and the exact amount of squeezed pore water in the syringe was determined gravimetrically. The squeezed pore-water samples were analysed by ICP-OES to determine $\mathrm{Ca}, \mathrm{Na}, \mathrm{K}$, $\mathrm{Mg}$ and $\mathrm{Fe}$ concentrations, by IC to determine sulfate and chloride concentrations, and by titration to determine bicarbonate according to the Gran method (Gran, 1950), and the $\mathrm{pH}$ value by an IrOx electrode (Muurinen, 2009; Itälä et al., 2013). The pore-water samples were kept in air-tight syringes before the bicarbonate and $\mathrm{pH}$ determinations. These last 
measurements were carried out inside an anoxic glovebox in closed vessels to minimize contact with the argon atmosphere $\left(\mathrm{CO}_{2}\right.$ content of $\left.<0.04 \mathrm{ppm}\right)$. The gas volume in the titration vessel was $100 \mathrm{~mL}$ and the sample size was $3 \mathrm{~mL}$. The $\mathrm{pH}$ change before titration was $\sim 1 \mathrm{pH}$ unit, which corresponds to a change of $<0.01 \mathrm{mM}$ in bicarbonate concentration. The estimated uncertainty for the IC and ICP-OES analyses was $\pm 20 \%$ and $\pm 10 \%$, respectively, according to the accredited laboratory ALS Finland Oy (Helsinki, Finland).

\section{Small angle $X$-ray scattering (SAXS)}

Samples for SAXS measurements were probed with a stainless steel cylindrical cutter $4 \mathrm{~mm}$ in diameter. The samples obtained were further cut into $0.3 \mathrm{~mm}$ slices. The slices were enclosed in metal rings and sealed tightly with thin polypropylene film to prevent drying during the measurement. All the preparations were carried out in a chamber with controlled relative humidity of $\sim 80 \%$. Reference samples were cut from the clay blocks, and the squeezed samples were probed directly in the squeezing cells.

The X-rays were generated with an X-ray tube with a $\mathrm{Cu}$-anode (PANalytical, Almelo, the Netherlands). The X-ray beam was collimated and monochromated to $\mathrm{Cu}-\mathrm{K} \alpha$ radiation $(1.54 \AA$ ) using a Montel-multilayer mirror. The scattered X-rays were collected using a Bruker Hi-Star area detector. Based on the scattering patterns, the average interlamellar distance was calculated and the mean stack size was estimated. Along with the specific surface area (Kumpulainen \& Kiviranta, 2011), these values were used to calculate the volume of the interlamellar pores (Matusewicz et al., 2013; Muurinen \& Carlsson, 2013).

\section{Nuclear magnetic resonance (NMR)}

The stainless steel cylindrical cutter (Ø $4 \mathrm{~mm})$ was also used to probe the reference samples from the clay blocks, and the squeezed samples from the squeezing cells. The clay sample from inside the cutter was pushed into a glass NMR tube $(4 \mathrm{~mm}$ inner $\varnothing)$ (Wilmad, USA) and closed tightly at both ends with polytetrafluoroethylene (PTFE) caps. The measurements of the samples were carried out using a highfield Chemagnetics CMX Infinity $270 \mathrm{MHz}$ NMR spectrometer with a $5 \mathrm{~mm}$ static ${ }^{1} \mathrm{H}$ NMR probe using a spin-locking Carr-Purcell-Meiboom-Gill (CPMG) technique (refocusing delay of $22 \mu \mathrm{s}$ ). The experiments were carried out at room temperature. The signal obtained from the method is the relaxation curve of the hydrogen nuclei in water molecules. The more confined the pore space is, the shorter is the relaxation time. A cut-off time of $510 \mu$ s was used here to separate the signal from the pore water in the nanopores, including the interlamellar pores, and remaining water (Ohkubo et al., 2008; Matusewicz et al., 2013).

\section{Geochemical modelling}

Geochemical modelling was based on the assumption that cations stay in the interlamellar space during squeezing and the deionized water from the IL space will mix with the non-IL pore water.

The modelling was performed using the PHREEQC code as a batch model (Parkhurst \& Appelo, 2013). In the first phase, calcite, gypsum, cation exchange and surface complexation sites were equilibrated with the assumed pore water composition in the bentonite. After that, in the second phase, the pore water was mixed with the assumed deionized IL water in the ratio determined by the NMR and SAXS measurements for bound and free water. Then in the third phase, the mixed water was equilibrated with bentonite to obtain the composition of the squeezed pore water in the syringe. The geochemical modelling was performed as a target calculation, where the composition of mixed water in the third phase was iterated to respond to the squeezed pore water by changing the pore-water composition in the first phase.

The surface complexation parameters were taken from Bradbury \& Baeyens (2002). The cation exchange parameters needed to be adjusted because after the ABM test in Äspö the bentonite was no longer the same as the initial MX-80. The initial Na-bentonite had equilibrated with various different bentonite materials and at the end of the ABM test was in a $\mathrm{Ca}$ form. Relevant cation exchange data, therefore, could not be found for these conditions in the literature. Thus, the cation exchange selectivity values were fixed so that the modelling results corresponded to experimental results. The cation-exchange parameters used are

TABLE 1. Cation exchange selectivity coefficients

\begin{tabular}{lc}
\hline Reaction & Selectivity coefficient \\
\hline${ }_{\mathrm{K} / \mathrm{Na}} K_{\mathrm{c}}$ & 8.51 \\
${ }^{\mathrm{Mg} / \mathrm{Na}} K_{\mathrm{c}}$ & 4.46 \\
${ }^{\mathrm{C} / \mathrm{Na}} K_{\mathrm{c}}$ & 8.32 \\
\hline
\end{tabular}




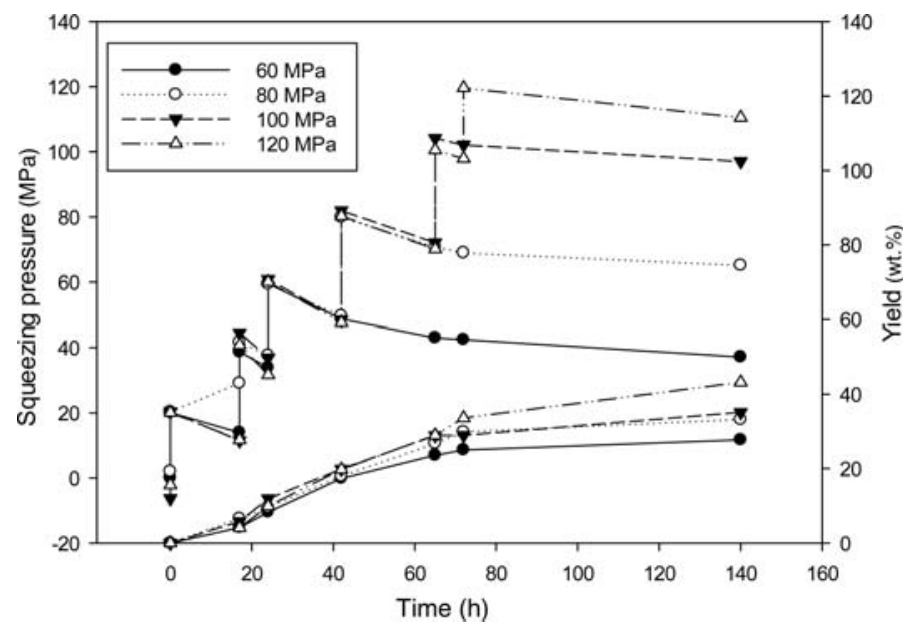

FIG. 3. Squeezing pressure and pore-water yield during the squeezing experiments as a function of time. The water yields were $32,38,41$ and $45 \mathrm{wt} . \%$ for maximum squeezing pressures of $60,80,100$ and $120 \mathrm{MPa}$, respectively.

presented in Table 1. The Thermoddem database was used for the modelling (Blanc et al., 2007).

\section{RESULTS}

\section{Squeezing}

Six days $(144 \mathrm{~h})$ was the time for squeezing the samples to reach an adequate yield of pore water but to minimize back diffusion of ions if the squeezed porewater was not in equilibrium with the bentonite. The initial dry density of the samples was $1.45 \mathrm{~g} / \mathrm{cm}^{3}$ and the maximum squeezing pressures $60,80,100$ and $120 \mathrm{MPa}$. The development of the squeezing pressures and yield of the pore water by squeezing are shown in Fig. 3.

The pore-water yield was calculated according to equation 1 , where, $m_{\mathrm{syr}}, m_{\mathrm{sinter}}$ and $m_{\text {tubes }}$ are balanced amounts of the water in the syringe, sinter and tubes, respectively, and $m_{\mathrm{H}_{2} \mathrm{O}}$ the total amount of water in the sample before squeezing, according to the water content measurements.

$$
\text { Yield }=\frac{m_{\text {syr }}+m_{\text {sinter }}+\mathrm{m}_{\text {tubes }}}{m_{\mathrm{H}_{2} \mathrm{O}}} \times 100 \%
$$

The recovery efficiency (RE \%) is the amount of squeezed pore water in the syringe divided by the loss of water from the clay sample during the squeezing according to water-content measurements before and after squeezing. The recovery efficiency is calculated according to equation 2 , where $m_{\text {dry }}$ is the dry weight of the sample, and wt. $\%_{\text {initial }}$ and wt. $\%_{\text {end }}$ are the water contents before and after squeezing, respectively.

$$
\mathrm{RE}=\frac{m_{\text {syr }}}{m_{\text {dry }} \times\left(\text { wt. }_{\text {initial }_{\text {ind }}}-\text { wt. } \%_{\text {end }}\right)} \times 100 \%
$$

The dry densities $\left(\rho_{\text {dry }}\right)$ were calculated according to equation 3 , whereby the water density $\rho_{\mathrm{H}_{2} \mathrm{O}}=1.00 \mathrm{~g} /$ $\mathrm{cm}^{3}$, grain density $\rho_{\mathrm{g}}=2.76 \mathrm{~g} / \mathrm{cm}^{3}$, and wt. $\%$ is the water mass per dry sample mass at $105^{\circ} \mathrm{C}$ (Karnland et al., 2006).

$$
\rho_{\text {dry }}=\frac{\rho_{\mathrm{H}_{2} \mathrm{O}} \times \rho_{\mathrm{g}}}{\rho_{\mathrm{g}} \times \frac{\mathrm{wt} . \%}{100 \%}+\rho_{\mathrm{H}_{2} \mathrm{O}}}
$$

The samples' total weight and water content were determined before squeezing. The mass of the squeezed pore water in the syringe, the final sample water content and water in the sinters were determined after squeezing. The average water volume of the connecting pipe and the sinter was $0.085 \mathrm{~mL}$. The calculated and measured values are presented in Table 2 .

Squeezing of all of the samples was started at the same time. The pressure was increased stepwise in $20 \mathrm{MPa}$ steps until the maximum pressure was reached. Before the samples were dismantled the pore water was collected for at least $60 \mathrm{~h}$ after reaching the maximum pressure. All the samples were dismantled at the same time.

There was a clear difference in the amount of the squeezed pore water obtained at the various squeezing pressures. The yield increased from 32 to $48 \mathrm{wt}$ \% when 
TABLE 2. Results from the squeezing experiments at different maximum pressures. The average initial values for dry density and water content were $1.45 \mathrm{~g} / \mathrm{cm}^{3}$ and $33.0 \mathrm{wt} . \%$, respectively.

\begin{tabular}{|c|c|c|c|c|c|c|c|}
\hline \multirow{2}{*}{$\begin{array}{l}\text { Maximum } \\
\text { squeezing pressure }\end{array}$} & \multirow{2}{*}{$\begin{array}{l}\text { Before } \\
\text { squeezing } \\
\text { sample wet } \\
\text { mass }\end{array}$} & \multicolumn{2}{|c|}{ After squeezing } & \multicolumn{2}{|c|}{ Water in } & \multicolumn{2}{|c|}{ Yield } \\
\hline & & $\begin{array}{l}\text { Dry } \\
\text { density }\end{array}$ & $\begin{array}{l}\text { Water } \\
\text { content }\end{array}$ & $\begin{array}{l}\text { Squeezed pore } \\
\text { water }\end{array}$ & $\begin{array}{l}\text { Sinter and } \\
\text { tubes }\end{array}$ & $\begin{array}{l}\text { From pore } \\
\text { water }\end{array}$ & $\begin{array}{l}\text { Recovery } \\
\text { ratio }\end{array}$ \\
\hline (MPa) & (g) & $\left(\mathrm{g} / \mathrm{cm}^{3}\right)$ & (wt.\%) & $(\mathrm{mL})$ & (g) & (wt.\%) & (wt.\%) \\
\hline 60 & 11.659 & 1.76 & 20.71 & 0.848 & 0.0881 & 32.4 & 78.7 \\
\hline 80 & 11.043 & 1.79 & 19.69 & 0.956 & 0.0819 & 37.9 & 86.6 \\
\hline 100 & 11.190 & 1.82 & 18.71 & 1.057 & 0.0852 & 41.2 & 88.0 \\
\hline 120 & 11.870 & 1.88 & 16.87 & 1.340 & 0.0846 & 48.4 & 93.1 \\
\hline
\end{tabular}

the maximum squeezing pressure increased from 60 to $120 \mathrm{MPa}$. The recovery ratio was better for samples with a higher squeezing pressure, obviously caused by the larger amount of water collected in the syringe.

\section{Pore-water analyses}

The chemical compositions of the squeezed and modelled pore waters are presented in Table 3. The Charge Balance Error (CBE, \%) was calculated based on the species in the Thermoddem database when using the PHREEQC code.

The CBE is clearly below the acceptable limit of $\pm 5 \%$. The variation in $\mathrm{pH}$ between samples was $<0.05 \mathrm{pH}$ units. No significant drop in ion concentrations as a function of the squeezing pressure was observed between the maximum pressures from 60 to $100 \mathrm{MPa}$.
A slight reduction in chloride, $\mathrm{Na}, \mathrm{K}$ and $\mathrm{Ca}$ contents was detected when the maximum squeezing pressure was increased from 100 to $120 \mathrm{MPa}$. These changes are below the uncertainty limit of the chemical analyses, however.

\section{Analytical results from the clay matrix}

The samples were dismantled after squeezing as indicated in Fig. 1. The four sub-samples selected for the squeezing tests were cut at an identical distance from the heater and height from the bottom of block 1, and thus were parallel. The concentrations of chlorides and sulfates in the bentonite for each sample before and after squeezing are listed in Table 4. The exchangeable cations and CEC results for each sample before and after squeezing are shown in

TABLE 3. Chemical composition of the squeezed (60-120 MPa) and modelled $(0 \mathrm{MPa}=$ non-IL water before squeezing) pore waters.

\begin{tabular}{lcccccc}
\hline & & & \multicolumn{4}{c}{ Squeezing pressure (MPa) } \\
\cline { 5 - 7 } Phase & Unit & 0 & 60 & 80 & 100 & 120 \\
\hline $\mathrm{pH}$ & $(-)$ & 7.7 & 7.7 & 7.7 & 7.7 & 7.7 \\
$\mathrm{Na}$ & $(\mathrm{mmol} / \mathrm{L})$ & 425 & 239 & 240 & 237 & 217 \\
$\mathrm{~K}$ & $(\mathrm{mmol} / \mathrm{L})$ & 3.9 & 2.1 & 2.2 & 1.8 & 1.6 \\
$\mathrm{Ca}$ & $(\mathrm{mmol} / \mathrm{L})$ & 110 & 62 & 62 & 67 & 59 \\
$\mathrm{Mg}$ & $(\mathrm{mmol} / \mathrm{L})$ & 46 & 25 & 24 & 25 & 25 \\
$\mathrm{Cl}^{-}$ & $(\mathrm{mmol} / \mathrm{L})$ & 712 & 381 & 375 & 384 & 355 \\
$\mathrm{SO}_{4}^{2-}$ & $(\mathrm{mmol} / \mathrm{L})$ & 13 & 7 & 7 & 6 & 7 \\
$\mathrm{Alkalinity}_{\text {Innic strength }}$ & $(\mathrm{meq} / \mathrm{L})$ & 0.7 & 3.6 & 3.9 & 3.3 & 3.4 \\
Charge balance error & $(\mathrm{M})$ & 0.84 & 0.47 & 0.47 & 0.48 & 0.44 \\
& $(\%)$ & - & 2.1 & 2.6 & 2.9 & 2.0 \\
\hline
\end{tabular}

The uncertainty for anion and cation analyses was $\pm 20 \%$ and $\pm 10 \%$, respectively. 
TABLE 4. Concentrations of carbonates, water-dissolving chloride and sulfate from samples before and after squeezing.

\begin{tabular}{|c|c|c|c|c|c|c|c|c|}
\hline \multirow{2}{*}{$\begin{array}{l}\text { Max. } \\
\text { S.P. } \\
(\mathrm{MPa})\end{array}$} & \multicolumn{4}{|c|}{ Before squeezing (0 MPa) } & \multicolumn{4}{|c|}{ After squeezing } \\
\hline & $\begin{array}{c}\text { C_org } \\
(\mathrm{mg} / \mathrm{g})\end{array}$ & $\begin{array}{l}\text { C_carb } \\
(\mathrm{mg} / \mathrm{g})\end{array}$ & $\begin{array}{c}\mathrm{Cl}^{-} \\
(\mathrm{mg} / \mathrm{g})\end{array}$ & $\begin{array}{c}\mathrm{SO}_{4}^{2-} \\
(\mathrm{mg} / \mathrm{g})\end{array}$ & $\begin{array}{l}\text { C_org } \\
(\mathrm{mg} / \mathrm{g})\end{array}$ & $\begin{array}{l}\text { C_carb } \\
(\mathrm{mg} / \mathrm{g})\end{array}$ & $\begin{array}{c}\mathrm{Cl}^{-} \\
(\mathrm{mg} / \mathrm{g})\end{array}$ & $\begin{array}{c}\mathrm{SO}_{4}^{2-} \\
(\mathrm{mg} / \mathrm{g})\end{array}$ \\
\hline 60 & 1.85 & 1.96 & 2.87 & 4.39 & 2.17 & 1.37 & 0.66 & 3.08 \\
\hline 80 & 1.61 & 2.18 & 2.39 & 3.86 & 2.44 & 1.58 & 0.58 & 2.90 \\
\hline 100 & 1.84 & 2.18 & 2.74 & 3.68 & 2.07 & 1.82 & 0.57 & 3.37 \\
\hline 120 & 1.95 & 2.80 & 2.4 & 4.02 & 2.88 & 0.77 & 0.47 & 3.40 \\
\hline Avg. & 1.81 & 2.28 & 2.60 & 3.99 & 2.39 & 1.39 & 0.57 & 3.19 \\
\hline SD & 0.14 & 0.36 & 0.24 & 0.30 & 0.36 & 0.45 & 0.08 & 0.24 \\
\hline
\end{tabular}

Max. S.P. $=$ maximum squeezing pressure, $\mathrm{SD}=$ standard deviation.

Table 5. Standard deviation (SD) was calculated from four parallel samples for ion content, exchangeable cations and CEC analyses. Twice the value of SD $(2 \times$ $\mathrm{SD})$ from each of the four parallel samples was used as the limit of error analyses, representing a $95 \%$ confidence level.

The $2 \times$ SD value between parallel samples was $\pm 0.7 \mathrm{mg} / \mathrm{g}, \pm 0.5 \mathrm{mg} / \mathrm{g}$ and $\pm 0.6 \mathrm{mg} / \mathrm{g}$ for carbonates, chloride and sulfate, respectively. A clear decrease in the chloride content and slight reductions in the carbonate and sulfate contents were observed after the squeezing experiments but not as a function of the squeezing pressure. The carbonate content in the samples was calculated by subtracting the amount of organic carbon from total carbon. A decrease in total carbon content was not observed before or after

TABLE 5. Cation exchange capacity (CEC) and exchangeable cations before and after squeezing.

\begin{tabular}{|c|c|c|c|c|c|}
\hline \multirow{2}{*}{$\begin{array}{l}\text { Max. } \\
\text { S.P. } \\
(\mathrm{MPa})\end{array}$} & \multirow[b]{2}{*}{$\begin{array}{c}\text { CEC } \\
\text { (meq/100 g) }\end{array}$} & \multicolumn{4}{|c|}{ Exchangeable cations } \\
\hline & & $\begin{array}{c}\mathrm{Ca} \\
(\text { meq \%) }\end{array}$ & $\begin{array}{c}\mathrm{K} \\
(\text { meq \%) }\end{array}$ & $\begin{array}{c}\mathrm{Mg} \\
(\text { meq \%) }\end{array}$ & $\begin{array}{c}\mathrm{Na} \\
\text { (meq \%) }\end{array}$ \\
\hline \multicolumn{6}{|c|}{ Before squeezing } \\
\hline 60 & 86.0 & 52.2 & 1.7 & 11.5 & 34.7 \\
\hline 80 & 86.9 & 53.6 & 1.8 & 10.8 & 33.8 \\
\hline 100 & 85.9 & 53.6 & 1.7 & 10.2 & 34.4 \\
\hline 120 & 86.5 & 52.8 & 1.9 & 11.5 & 33.9 \\
\hline Average & 86.3 & 53.1 & 1.8 & 11.0 & 34.2 \\
\hline SD & 0.46 & 0.69 & 0.09 & 0.63 & 0.42 \\
\hline \multicolumn{6}{|c|}{ After squeezing } \\
\hline 60 & 85.7 & 53.6 & 1.8 & 10.8 & 33.8 \\
\hline 80 & 87.1 & 52.3 & 1.9 & 10.6 & 34.2 \\
\hline 100 & 87.2 & 54.0 & 1.8 & 11.0 & 33.2 \\
\hline 120 & $\mathrm{OL}$ & 53.1 & 1.7 & 11.1 & 34.1 \\
\hline Average & 86.7 & 53.3 & 1.8 & 10.9 & 33.8 \\
\hline SD & 0.84 & 0.73 & 0.08 & 0.22 & 0.45 \\
\hline
\end{tabular}

OL: excluded as an outlier (83.8).

$\mathrm{SD}=$ standard deviation .

Max S.P. $=$ Maximum squeezing pressure. 


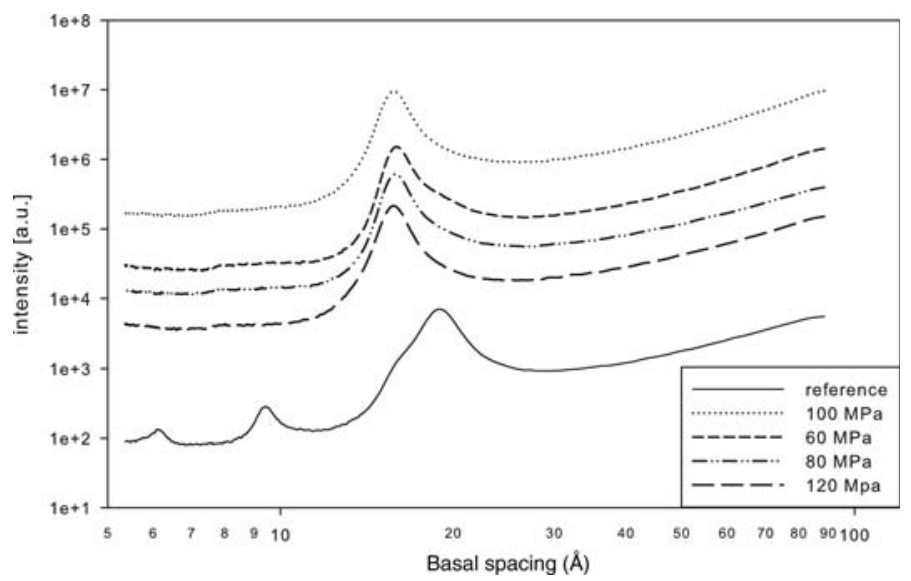

FIG. 4. Scattering intensities of montmorillonite in the reference sample and squeezed samples as a function of basal spacing.

squeezing. Thus, changes in the carbonate content before and after squeezing seem to be more dependent on the analytical method than due to a real decrease in carbonate content; these data were therefore excluded from interpretations of the results.

The chloride-accessible porosity was calculated according to equation 4 , where $m_{\mathrm{Cl}}$ is the chloride mass in the sample $(\mathrm{g}), m_{\mathrm{b}}$ is sample dry mass $(\mathrm{g}), \rho_{\mathrm{g}}$ is grain density of the clay $\left(\mathrm{g} / \mathrm{cm}^{3}\right), V_{\mathrm{w}}$ is the water volume in the sample $\left(\mathrm{cm}^{3}\right)$ and $C_{\mathrm{Cl}}^{\mathrm{o}}$ is the chloride concentration $\left(\mathrm{g} / \mathrm{cm}^{3}\right)$ in the external solution (Muurinen \& Carlsson, 2013).

$$
\varepsilon_{\mathrm{Cl}}=\frac{m_{\mathrm{Cl}}}{\left(\frac{m_{\mathrm{b}}}{\rho_{\mathrm{g}}}+V_{\mathrm{w}}\right) C_{\mathrm{Cl}}^{0}}
$$

The chloride-accessible porosities were $23,7.9,7.2$, 7.1 and 6.6 vol.\% for samples with maximum squeezing pressures of $0,60,80,100$ and $120 \mathrm{MPa}$, respectively, when squeezed pore-water chloride concentrations were $C_{\mathrm{Cl}}^{\mathrm{o}}$.

The $2 \times$ SD value between the parallel samples was $<1.0 \mathrm{meq} / 100 \mathrm{~g}$ and $1.4 \mathrm{meq} \%$ for the CEC and exchangeable cations, respectively. The CEC and exchangeable cation compositions were similar for the different squeezing pressures and the samples before and after squeezing. The CEC for the samples after $120 \mathrm{MPa}$ squeezing differs by $>\sim 3$ times the SD value. Such a big difference in CEC value would mean structural changes in montmorillonite, and thus the value is expected to be an outlier and is excluded from the interpretation of the results.

\section{SAXS AND NMR}

The X-ray scattering curves show a clear difference between the reference sample and the squeezed samples (Fig. 4). For the reference sample, the position of the main peak is at $18.6 \AA$ which corresponds to three water layers in the interlamellar space. A clear shoulder is visible at $\sim 16 \AA$ which suggests that some of the interlamellar pores have two water layers. For the squeezed samples, a single peak close to $16 \AA$ is observed, suggesting that most of the interlamellar spaces are filled with two water layers. Small differences were also observed between the squeezed samples. The position of the peak shifts slightly towards smaller distances with an increase in the squeezing pressure (Fig. 5).

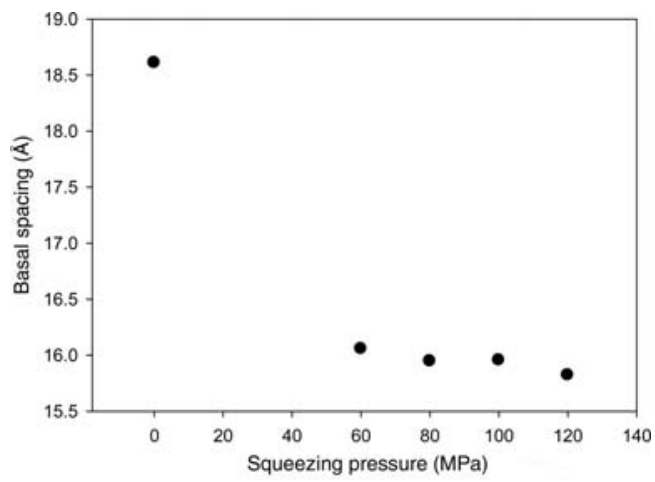

FIG. 5. Variation of basal spacing of montmorillonite as a function of squeezing pressure. 


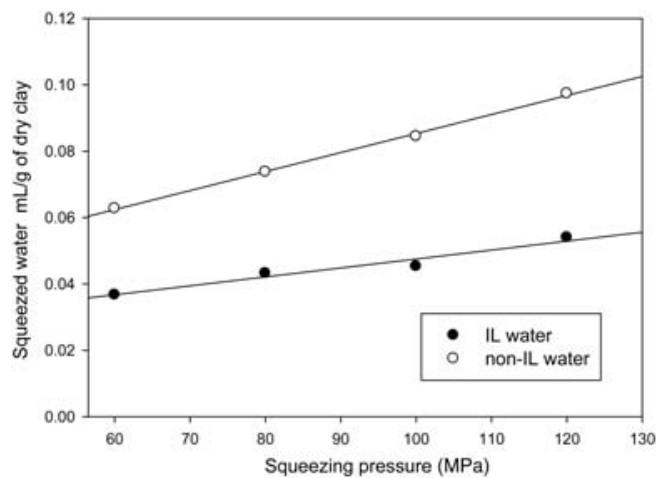

FIG. 6. IL and non-IL water squeezed from the sample average of two samples used for $100 \mathrm{MPa}$.

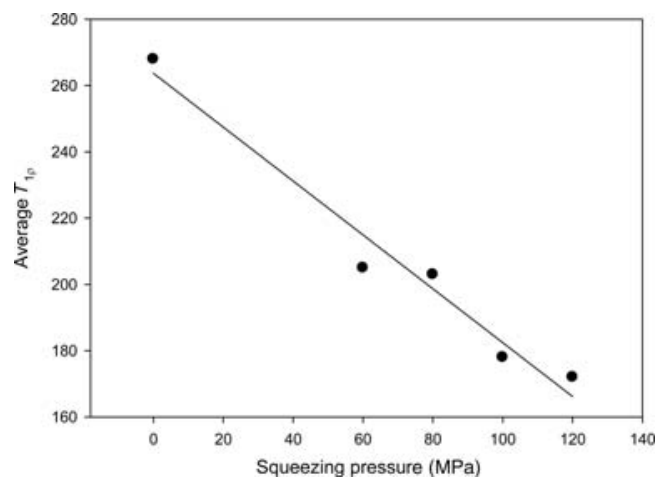

FIG. 7. Average relaxation time as a function of squeezing pressure.

The amount of pore water squeezed out, normalized to $1 \mathrm{~g}$ of dry clay mass, is shown in Fig. 6. The squeezed water volume increases linearly with the increasing pressure applied. Approximately $35 \mathrm{wt} . \%$ of the collected pore water comes from the IL pores. The proportion of pore water squeezed from the interlamellar spaces and from the remaining pore volume is constant in the pressure range measured.

The analysis of the NMR $T_{1 \rho}$ relaxation times shows that the average relaxation time of the samples moves to a faster time for samples squeezed with greater pressure. The larger pores disappear and the average pore size becomes smaller (Fig. 7). A clear linear trend is observed between the average relaxation time and the increasing squeezing pressure.

The estimated IL and non-IL porosity values obtained by SAXS and NMR are listed in Table 6 . The values calculated from the NMR results seem to underestimate non-IL porosity because the decay of the time measured signal in the CPMG experiment is proportional to the pore size (smaller decay time, smaller pores). In very high-density samples the difference between the average size of the pores between the clay particles and the interlamellar pores is not large enough to resolve between the two pore types with this method.

\section{Interpretation}

Four parallel fully saturated MX-80 bentonite samples were squeezed from an initial dry density of $1.45 \mathrm{~g} / \mathrm{cm}^{3}$ to $1.76,1.79,1.82$ and $1.88 \mathrm{~g} / \mathrm{cm}^{3}$, by maximum squeezing pressures of $60,80,100$ and $120 \mathrm{MPa}$, respectively. The total water content of the samples before squeezing was 33 wt. $\%$, which corresponds to $0.33 \mathrm{~mL} / \mathrm{g}$ of dry clay at $105^{\circ} \mathrm{C}$, where $0.11 \mathrm{~mL} / \mathrm{g}_{\text {clay }}$ was from non-IL space according to the SAXS measurements (Table 6). 32-48 wt.\% of pore water was successfully squeezed out, which corresponds to a loss in total water of 0.11 and $0.16 \mathrm{~mL} / \mathrm{g}$ of bentonite (Table 2).

The microstructural analysis shows a significant difference in the clay structure between the reference

TABLE 6. Comparison of IL and non-IL porosity based on SAXS and NMR measurements.

\begin{tabular}{lccccccc}
\hline & & \multicolumn{3}{c}{ SAXS } & & \multicolumn{2}{c}{ NMR } \\
\cline { 8 - 8 } \cline { 7 - 8 } $\begin{array}{l}\text { Squeezing } \\
\text { pressure (MPa) }\end{array}$ & $\begin{array}{c}\text { Total porosity } \\
(\text { vol. \%) }\end{array}$ & $\begin{array}{c}\text { Avg IL } \\
\text { distance }(\AA)\end{array}$ & $\begin{array}{c}\text { IL porosity } \\
(\text { vol. \%) }\end{array}$ & $\begin{array}{c}\text { Non-IL porosity } \\
\text { (vol. \%) }\end{array}$ & & $\begin{array}{c}\text { IL porosity } \\
\text { (vol. \%) }\end{array}$ & $\begin{array}{c}\text { Non-IL porosity } \\
\text { (vol. \%) }\end{array}$ \\
\hline 0 & 0.49 & 18.6 & 0.33 & 0.16 & & 0.46 & 0.03 \\
60 & 0.37 & 16.1 & 0.30 & 0.07 & & 0.37 & 0.00 \\
80 & 0.36 & 15.9 & 0.30 & 0.05 & & 0.36 & 0.00 \\
100 & 0.35 & 16.0 & 0.31 & 0.04 & & 0.35 & 0.00 \\
120 & 0.32 & 15.8 & 0.31 & 0.02 & & 0.32 & 0.00 \\
\hline
\end{tabular}




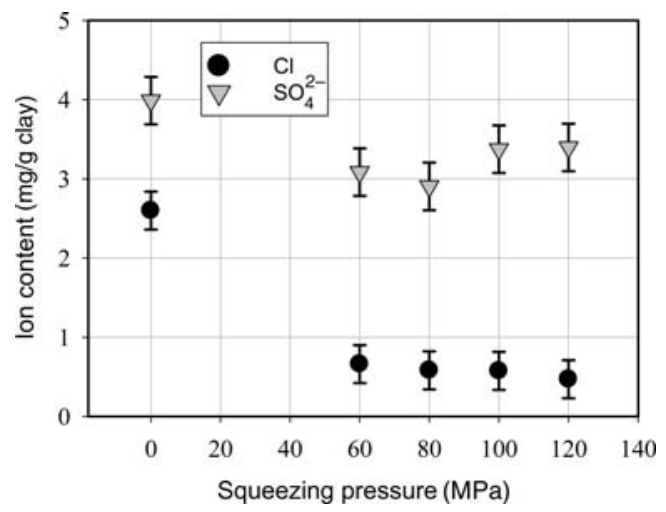

FIG. 8. Chloride and sulfate content as $\mathrm{Cl}$ and $\mathrm{SO}_{4}^{2-}$, respectively, in the clay matrix $(\mathrm{mg} / \mathrm{g}$ of dry clay). The reference sample $(0 \mathrm{MPa})$ is the average of four parallel samples and the error bar is two times the standard deviation for these samples.

sample and the squeezed samples. A clear reduction in the average basal spacing was observed for an increase in squeezing pressure from 0 to $60 \mathrm{MPa}$, and a less significant but yet notable decrease was seen as the pressure increased to 80,100 and then $120 \mathrm{MPa}$ (Fig. 5). At the same time, a decrease was also observed in the volume of the larger pores. The decrease in the calculated values of the porosity shows that the proportion of pore water squeezed from the IL and non-IL pores is constant (Fig. 6).

A clear reduction in the chloride content was observed before and after squeezing (Fig. 8). The calculated chloride-accessible porosities according to equation 4 and based on the analysed values of chloride in the clay matrix and squeezed porewater were $6.6-7.9$ vol. $\%\left(\rho_{\text {dry }}=1.88-1.76 \mathrm{~g} / \mathrm{cm}^{3}\right)$ for the squeezed samples and 23 vol. $\%\left(\rho_{\text {dry }}=1.45 \mathrm{~g} / \mathrm{cm}^{3}\right)$ for the reference sample. These volumes are greater than the measured non-IL porosities using SAXS (2-7 vol.\% for the squeezed samples and 16 vol. $\%$ for the reference sample). The external water chloride concentration was therefore set at $1 \mathrm{M}$, when the $\mathrm{Cl}$ accessible porosities decreased to values of $2-3$ vol.\% for the squeezed samples and to 8.6 vol.\% for the reference sample. These values match perfectly with Van Loon et al. (2007) with Cl-accessible porosities of $9 \pm 2$ and $3.5 \pm 1$ vol. $\%$ determined for similar material at 1.6 and $1.9 \mathrm{~g} / \mathrm{cm}^{3}$ dry densities, respectively, in $1 \mathrm{M}$ $\mathrm{NaCl}$ solution.

The proportion of the IL, non-IL and chlorideaccessible space is presented in Fig. 9. The results match well with previous studies concerning the microstructure of bentonite by Muurinen \& Carlsson (2013).

No significant variation in the chemical composition of the squeezed pore water was observed when the

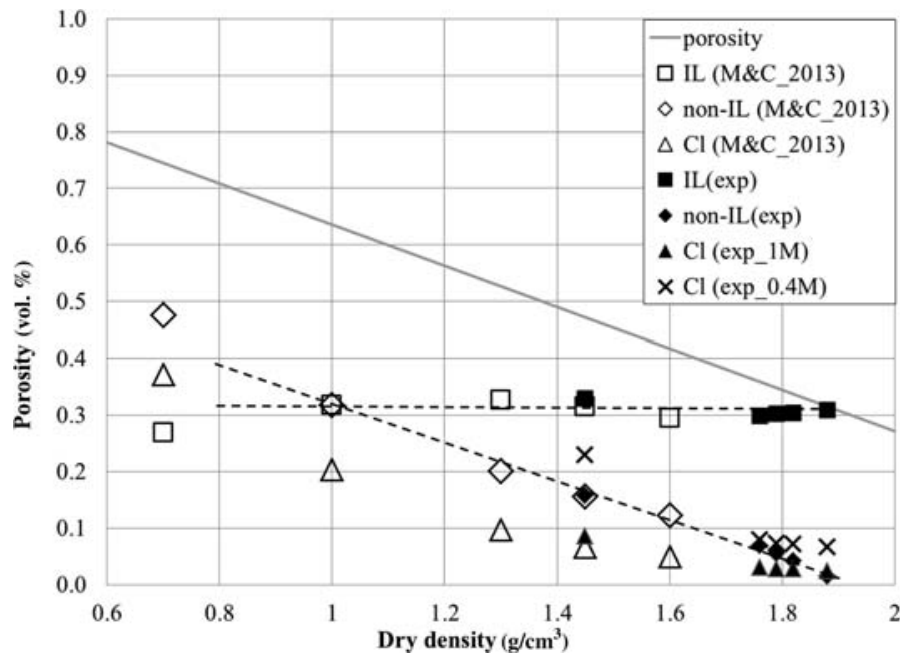

FIG. 9. Porosity vs. dry density. $\mathrm{Cl}$ is chloride-accessible porosity, IL and non-IL are interlamellar and non-interlamellar porosity, respectively. Exp refers to values measured in the present study. M\&C_2013 refers to Muurinen \& Carlsson (2013). Dotted lines refer to IL and non-IL porosities vs. dry density. $1 \mathrm{M}$ (estimated Cl concentration in Cl-accessible water) and $0.4 \mathrm{M}$ (squeezed pore-water $\mathrm{Cl}$ concentration) refers to external water $\mathrm{Cl}$ concentrations used to calculate chloride-accessible porosity. Reference sample dry density $=1.45 \mathrm{~g} / \mathrm{cm}^{3}$. 


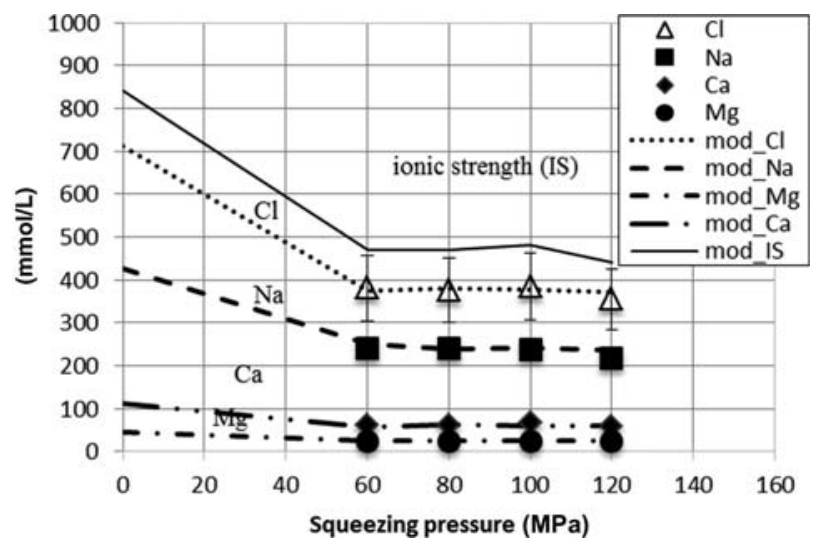

FIG. 10. Exchange isotherm of $\mathrm{Na}^{+}$on montmorillonite: squeezed water, as calculated from the squeezed-water composition and exchangeable cations in the present.

pore-water yield increased from 32 to $41 \mathrm{wt} \%$, i.e. from 60 to $100 \mathrm{MPa}$; a slight dilution of $\mathrm{Na}$ and chloride was observed, however, when squeezed porewater yield increased to $48 \mathrm{wt} . \%$ (Table 3 ).

The modelled results for the initial non-IL and squeezed pore-water compositions are presented together with the squeezed pore-water composition in Figs 10 and 11. The anion-accessible porosities, and diffusion or kinetic limitations were not included in the model.

According to the modelling, the non-IL pore water ionic strength was $\sim 0.840 \mathrm{M}$ which decreased to $0.460 \mathrm{M}$ due to the mixing by IL water during the squeezing process at the pressures studied. The initial non-IL water chloride concentration $(0.7 \mathrm{M})$ according to modelling is smaller than the value $(1 \mathrm{M})$, which corresponds to the chloride-accessible porosities determined by Van Loon et al. (2007).

A slight decrease in the total amount of sulfate content was observed to occur during the squeezing according to the clay matrix analyses (Fig. 8). This could be attributed to the dissolution of sulfate due to the mixing of different water types. Only minor concentrations of sulfate $(0.7 \mathrm{mM})$ in the squeezed pore water were analysed. According to geochemical modelling, the dilution of non-IL water dissolves gypsum and calcite at the level of the minerals'

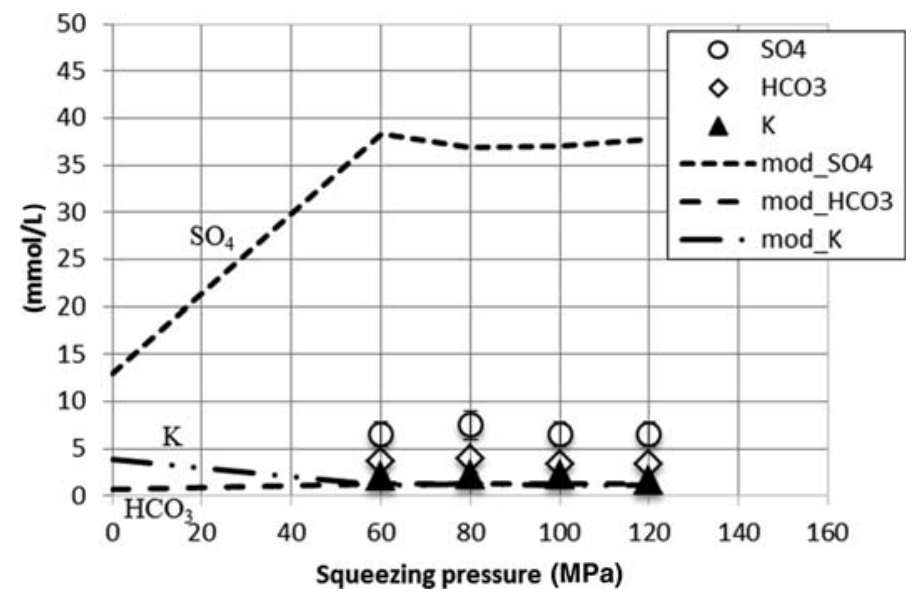

FIG. 11. Initial non-IL water composition according to modelling ( $0 \mathrm{MPa})$, and squeezed pore-water $(60$, 80 , 100 , $120 \mathrm{MPa}$ ) composition according to modelling and experimental results for the main ions. Lines indicate modelling and dots indicate experimental results. 
saturation limits, changing the $\mathrm{Na} / \mathrm{Ca}$ ratio in non-IL water. The exchanger will rebalance the cation ratio and increase dissolution of these accessory minerals. Due to the reaction chain, the sulfate and bicarbonate concentrations should be greater in squeezed pore water than in initial non-IL water (Fig. 11). Such low sulfate concentrations in squeezed pore water may be attributed to the limited space of anions in the real system. This may cause limited migration of large negatively charged ions and greater anion concentrations next to the minerals than predicted by geochemical modelling. Bicarbonate concentration was determined through alkaline titration. Due to the low alkalinity, other compounds such as silicates, organic anions and sulfides may affect the value. This may partly explain high bicarbonate cconcentrations compared with those predicted by geochemical modelling.

Changes before and after squeezing in the exchangeable cation content were not observed (Table 4). The concentration of cations in the squeezed pore water was $<6$ meq \% compared to the CEC of the exchanger, and therefore the possible changes in the cation exchanger cannot be observed in the analyses. The measured $\mathrm{Na}$ fraction in the squeezed solution and the exchangeable cations were $\sim 0.77$ and 0.33 meq, respectively. In cation-exchange experiments of Na-montmorillonite, the corresponding $\mathrm{Na}$ equivalent fraction in solution should be $\sim 0.9 \mathrm{meq}$ or $0.2 \mathrm{meq}$ in the exchanger (Sposito et al., 1983). The different ionic strength established by Sposito et al. (1983) and in the present experiment were taken into account by using chemical activities in the calculations (Fig. 12).

The model presented describes the system to some degree but shows that dividing waters into two different

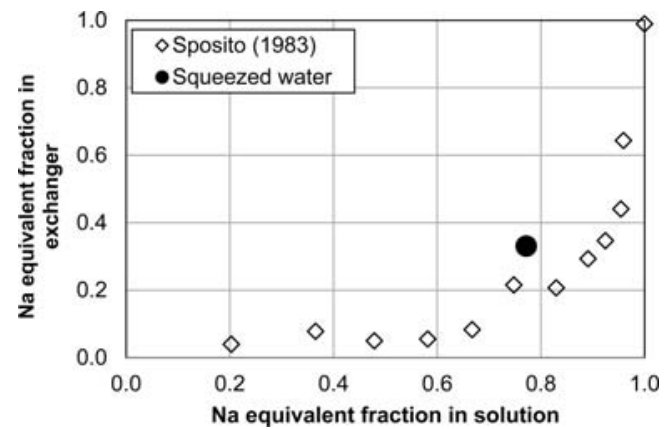

FIG. 12. Initial non-IL water composition according to modelling (0 MPa), and squeezed $(60,80,100,120 \mathrm{MPa})$ pore-water composition according to modelling and experimental results for the minor ions. Lines indicate modelling and dots indicate experimental results. water types with simplified compositions cannot explain all the observations. The limited space for anions in non-IL water should be taken into account, as well as varying cation ratios in non-IL water. As anion concentrations are thought to change with the distance from negatively charged surfaces, the change of cation ratios in non-IL pore water could also be considered.

There is some evidence indicating that the squeezed pore water composition is a mixture of different porewater types with varying ion concentrations in the squeezing pressure range studied. (1) The decrease in the measured IL, non-IL and Cl-accessible volumes during squeezing indicates mixing of these water types (Fig. 9). (2) The calculated chloride-accessible porosities according to squeezed pore-water chloride concentrations were greater than the measured non-IL porosities (Fig. 9). (3) The imbalance between the squeezed pore water and the cation exchanger indicates that cation composition has changed. A sodium concentration that is too low compared to other cations, indicates that additional calcium was released (Fig. 12).

Rebalancing between squeezed pore water in the syringe and pore water in bentonite was prevented by choosing a relatively short squeezing time (6 days). With a much longer squeezing time, an increase in concentrations of chloride, $\mathrm{Na}$ and sulfate and a decrease in concentration of $\mathrm{Ca}$ in squeezed pore water in the syringe is expected according to imbalances between bentonite and squeezed pore water observed in these experiments.

\section{CONCLUSIONS}

Squeezing experiments, the determination of the chemical composition of aqueous and solid phases and the microstructural analysis of the solid phase, were carried out successfully on ABM samples. The results obtained were used in geochemical modelling with the PHREEQC program by mixing IL and non-IL waters in fractions determined by microstructural analysis by means of SAXS measurements.

The pore-water yield increased from 32 to $48 \mathrm{wt} . \%$ from the initial amount of pore water in the samples when the squeezing pressure increased from 60 to $120 \mathrm{MPa}$. About $35 \mathrm{wt} \%$ of collected pore water comes from the IL pores. The ratio between IL and non-IL pore waters, as well as the composition of the squeezed pore water, was constant in this squeezingpressure range. The results of microstructural measurements by SAXS agree well with previous studies by Muurinen \& Carlsson (2013). 
Dissolving accessory minerals affects the ratio of cations in the squeezed solution. The limited space for anions in non-IL water affects the chemical activities of the anions and should be taken into account in geochemical modelling. The chloride concentration of the non-IL pore water in compacted bentonite before squeezing was $0.34 \mathrm{M}$ greater than in squeezed pore water, due to the mixing of two main water types.

\section{ACKNOWLEDGEMENTS}

The research leading to these results received funding from Posiva Oy (Finland). Andrew Root (MagSol) is acknowledged for carrying out NMR measurements. The authors thank the Alternative Buffer Material (ABM) project and Clay Tech for the opportunity to use the samples for these experiments. Dr A. Muurinen, Dr T. Carlsson and Prof. M. Olin are acknowledged for discussions and ideas on the subject. Dr A.M. Fernández and Dr H. Van Baelen are acknowledged for many constructive comments and suggestions on the manuscript.

\section{REFERENCES}

Amman L., Bergaya F. \& Lagaly G. (2005) Determination of the cation exchange capacity of clays with copper complexes revisited. Clay Minerals, 40, 441-453.

Blanc P., Lassin A. \& Piantone P. (2007) THERMODDEM - A database devoted to waste minerals: (http://thermoddem.brgm.fr).

Bolt G.H. \& Warkentin B.P. (1958) The negative adsorption of anions by clay suspensions. KolloidZeitschrift, 156, 41-46.

Bradbury M.H. \& Baeyens B. (2002) Pore water chemistry in compacted re-saturated $M X-80$ bentonite: Physico-chemical characterisation and geochemical modelling. Paul Scherrer Institut Berich Nr. 02-10, Villigen, Switzerland, 42 pp.

Fernández A.M., Baeyens B., Bradbury M. \& Rivas P. (2004) Analysis of the pore water chemical composition of a Spanish compacted bentonite used in an engineered barrier. Physics and Chemistry of the Earth, 29, 105-118.

Fernández A.M., Sanchez-Ledesma D.M., Tournassat C., Melon A., Gaucher E.C., Astudillo J. \& Vinsot A. (2014) Applying the squeezing technique to highly consolidated clayrocks for pore water characterization: Lessons learned from experiments at the Mont Terri Rock Laboratory. Applied Geochemistry, 49, 2-21.

Fernández A.M., Wilhelm S., Wouters L. \& Van Baelen H. (2015) Characterizing clay pore water composition of Ypresian clays from Doel and Kallo sites, Belgium. 6th meeting on "Clays in Natural \& Engineered
Barriers for Radioactive Waste Confinement". Book of Abstracts, pp. 202-203.

Gran G. (1950) Determination of the equivalence point in potentiometric titration. Acta Chemica Scandinavica, 4, 559-577.

Holmboe M., Wold S. \& Jonsson M. (2012) Porosity investigation of compacted bentonite using XRD profile modelling. Journal of Contaminant Hydrology, 128, 19-32.

Itälä A., Järvinen J. \& Muurinen A. (2013) $\mathrm{CO}_{2}$ effect on the $\mathrm{pH}$ of compacted bentonite buffer on the laboratory scale. Clay Minerals, 48, 149-152.

Karnland O., Olsson S. \& Nilsson U. (2006) Mineralogy and sealing properties of various bentonites and smectite-rich clay minerals. Swedish Nuclear Fuel and Waste Management, Stockholm, Sweden, SKB Technical Report TR-06-30.

Kiviranta L. \& Kumpulainen S. (2011) Quality control and characterization of bentonite materials. Posiva Oy, Olkiluoto, Finland, Working Report 2011-84.

Kumpulainen S. \& Kiviranta L. (2010) Mineralogical and chemical characterization of various bentonite and smectite-rich clay materials. Part A. Comparison and development of mineralogical characterization methods Part B: Mineralogical and chemical characterization of clay materials. Posiva Oy, Olkiluoto, Finland, Working Report 2010-52, 74 p.

Kumpulainen S. \& Kiviranta L. (2011) Mineralogical, Chemical and Physical Study of Potential Buffer and Backfill Materials from ABM Test Package 1. Posiva Oy, Olkiluoto, Finland, Working Report 2011-41.

Matusewicz M., Liljeström V., Pirkkalainen P., Suurinen J. P., Root A., Muurinen A., Serimaa R. \& Olin M. (2013) Microstructural investigation of calcium montmorillonite. Clay Minerals, 48, 267-276.

Meier L.P. \& Kahr G. (1999) Determination of the cation exchange capacity (CEC) of clay minerals using the complexes of copper(II) ion with triethylenetetramine and tetraethylenepentamine. Clays and Clay Minerals, 47, 386-388.

Muurinen A. (2001) Development and testing of analysis methods for bentonite pore water. Posiva Oy, Olkiluoto, Finland, Working Report 2001-07.

Muurinen A. (2006) Ion concentration caused by an external solution into the porewater of compacted bentonite. Posiva Oy, Olkiluoto, Finland, Working Report 2006-96.

Muurinen A. (2009) Studies on the chemical conditions and microstructure in the reference bentonites of alternative buffer materials project (ABM) in Äspö. Posiva Oy, Olkiluoto, Finland. Working Report 2009-42.

Muurinen A. (2010) Studies on the chemical conditions and microstructure in package 1 of alternative buffer materials project $(A B M)$ in Äspö. Posiva Oy, Olkiluoto, Finland. Working Report 2010-11. 
Muurinen A. \& Carlsson T. (2013) Bentonite pore structure based on SAXS, chloride exclusion and NMR studies. Posiva Oy, Olkiluoto, Finland. Working Report 2013-53.

Muurinen A. \& Järvinen J. (2013) Ion-selective electrodes in pore water chemistry measurement of compacted bentonite. Posiva Oy, Olkiluoto, Finland. Working Report 2013-24.

Muurinen A. \& Lehikoinen J. (1999) Pore water chemistry in compacted bentonite. Posiva Oy, Olkiluoto, Finland, Working report 1999-20.

Muurinen A., Karnland O. \& Lehikoinen J. (2007) Effect of homogenization on the microstructure and exclusion of chloride in compacted bentonite. Physics and Chemistry of the Earth, Parts $A / B / C, 32,485-490$.

Ohkubo T., Kikuchi H. \& Yamaguchi M. (2008) An approach of NMR relaxometry for understanding water in saturated compacted bentonite. Physics and Chemistry of the Earth, 33, S169-S176.

Parkhurst D.L. \& Appelo C.A.J. (2013) Description of input and examples for PHREEQC version 3 - A computer program for speciation, batch-reaction, one-dimensional transport, and inverse geochemical calculations. U.S. Geological Survey Techniques and Methods, book 6, chapter A43, 497 pp. (http://pubs. usgs.gov/tm/06/a43/)

Posiva (2010) Nuclear Waste Management at Olkiluoto and Loviisa Power Plants: Review of Current Status and Future Plans for 2010-2012. TKS-2009, Posiva OY, Eurajoki.
Pusch R., Muurinen A., Lehikoinen J., Bors J. \& Eriksen T. (1999) Microstructural and chemical parameters of bentonite as determinants of waste isolation efficiency. European Commission. Nuclear Science and Technology. Project Report EUR 18950 EN.

Sacchi E., Michelot J.-L., Pitsch H., Lalieux P. \& Aranyossy J. (2001) Extraction of water and solutes from argillaceous rocks for geochemical characterisation: Methods, processes and current understanding. Hydrogeology Journal, 9, 17-33.

SKB (2011) Long-term safety for the final repository for spent nuclear fuel at Forsmark. TR-11-01, Svensk Kärnbränslehantering $\mathrm{AB}$, Stockholm.

Sposito G., Holtzclaw K.M., Charlet L., Jouany C. \& Page A.L. (1983) Sodium-calcium and sodium-magnesium exchange on Wyoming bentonite in perchlorate and chloride media. Soil Science Society of America Journal, 47, 51-56.

Svensson D., Duek A., Nilsson U., Olsson S., Sandén T., Lydmark S., Jägerwall S., Pedersen K. \& Hansen S. (2011) Alternative buffer material. Status of the ongoing laboratory investigation of reference materials and test package 1. SKB, TR-11-06.

Van Loon L.R., Glaus M.A. \& Muller W. (2007) Anion exclusion effects in compacted bentonites: Towards a better understanding of anion diffusion. Applied Geochemistry, 22, 2536-2552.

Wersin P. (2003) Geochemical modelling of bentonite pore water in high-level water repositories. Journal of Contaminant Hydrology, 61, 405-422. 